ROCZNIK POLSKO-NIEMIECKI 2020, nr 28

ISSN $1230-4360$

DOI 10.35757/RPN.2020.28.10

\title{
Matgorzata Świder
}

Uniwersytet Pedagogiczny im. Komisji Edukacji Narodowej

w Krakowie

ORCID 0000-0002-4354-3641

malgorzata.swider@up.krakow.pl

\section{Obywatele Niemiec Wschodnich wobec zjednoczenia niemiecko-niemieckiego i przesiedleń do RFN w świetle tajnych badań opinii publicznej (jesień 1989 - wiosna 1990)}

W czasie przełomu społeczno-politycznego (jesień 1989-wiosna 1990) instytucje z NRD i RFN prowadziły badania opinii publicznej, które miały służyć poznaniu poglądów społeczeństwa wschodnioniemieckiego na aktualne, nierzadko polaryzujące tematy. Wśród kluczowych zagadnień było: zjednoczenie Niemiec, poparcie dla poszczególnych partii i polityków czy szybkość zachodzących przemian. Równie ważne były pytania odnoszące się do sytuacji osobistej respondentów w kontekście wzmożonej migracji obywateli NRD do RFN. Pytanie: „Wyjadą czy zostaną?”, stało się aktualne wraz z ,wyłomem w murze”, jakiego dokonano 9 listopada 1989 roku $^{1}$ i było zadawane

1 W dniu 9 listopada 1989 roku władze NRD zapowiedziały swobodę podróżowania i zburzenie muru, co w praktyce oznaczało jego otwarcie. Decyzję ogłosił Günter Schabowski, pierwszy sekretarz SED w Berlinie Wschodnim i sekretarz komitetu centralnego SED ds. Informacji bez skonsultowana jej ze stroną radziecką. E. Cziomer, Przestanki konfliktu Wschód-Zachód na przetomie lat 80. i 90. oraz skutki jego przezwyciężenia, w: E. Cziomer (red.), Międzynarodowe stosunki polityczne, Krakowska Szkoła Wyższa im. Andrzeja Frycza Modrzewskiego, Kraków 2008, s. 246. Więcej zob.: M. Cygański, Polityka niemiecka RFN wobec NRD w latach 1969-1989/1990, Instytut Śląski w Opolu, Opole 1990, s. 158; H. Kulick, 9. November 1989. Der Mauerfall aus vielen Perspektiven, Bundeszentrale für politische Bildung, 9. November 2019, https://www.bpb. de/geschichte/zeitgeschichte/deutschlandarchiv/299911/der-mauerfall-aus-vielen-perspektiven 
w prowadzonych wówczas po obu stronach niemiecko-niemieckiej granicy tajnych badaniach sondażowych.

W niniejszym tekście poddano analizie materiały archiwalne odnoszące się do tajnych badań opinii publicznej realizowanych w NRD i w RFN². Zwrócono przy tym szczególną uwagę na wyniki owych sondaży w dwóch zasadniczych kwestiach: stosunku obywateli NRD do zjednoczenia Niemiec, a także problemu wzmożonych wyjazdów do RFN. Oczywiście badania, o których mowa będzie dalej, nie ograniczały się tylko do tych dwóch zagadnień, ale zawierały wiele innych pytań, które pozwalały zajrzeć w głąb społeczeństwa NRD, zbadać jego poglądy i aktywność polityczną z przełomu 1989 i 1990 roku. W tym kontekście podjęto próbę (bardzo ograniczoną z racji reglamentowanego dostępu do badań prowadzonych przez Federalną Służbę Wywiadowczą - Bundesnachrichtendienst (dalej: BND) ${ }^{3}$ ) ukazania wyników zarówno wschodnio-, jak i zachodnioniemieckich sondaży opinii publicznej w wątkach dotyczących zjednoczenia Niemiec i opuszczenia NRD. Dla lepszego zrozumienia zachodzących wówczas procesów analizę pozyskanych danych wzbogacono informacjami i analizami retrospektywnymi. Prezentacja ta zostanie poprzedzona wskazaniem zasadniczych różnic $\mathrm{w}$ traktowaniu badań opinii publicznej w obu państwach niemieckich, a także omówieniem głównych instytucji prowadzących badania socjologiczne, którymi objęci byli obywatele NRD. Na uwagę zasługuje niestandardowa metodologia stosowana przez zachodnioniemieckie ośrodki, które nawiązywały do prowadzonych wcześniej tego typu sondaży. Podstawą opracowania są materiały archiwalne wytworzone przez powstałą 1 kwietnia 1956 roku BND i zdeponowane w Bundesarchiv (Archiwum Federalnym w Koblencji),

2 W niniejszym tekście nie brano pod uwagę wyników prowadzonych przez BND przesłuchań osób, które uciekły z NRD, ani też wyników obserwacji obywateli Niemiec Wschodnich prowadzonych przez Stasi, wychodząc z założenia, że tego typu zbieranie informacji nie miało charakteru badania opinii publicznej. Część tajnych sprawozdań przygotowanych przez Stasi dla polityków państwowych i partyjnych została opublikowana w serii: Die DDR im Blick der Stasi. Raporty pochodzą z lat 1953-1989 i ujawniają specyficzny pogląd Stasi na NRD. Między innymi zawierają informacje o gospodarce i zaopatrzeniu, a także o zachowaniach opozycyjnych, jak również statystyki dotyczące ucieczek z NRD i wniosków o przesiedlenie do RFN. Z punktu widzenia niniejszego tekstu na szczególne podkreślenie zasługuje tom: M. Schiefer, M. Stief (red.), Die DDR im Blick der Stasi 1989. Die geheimen Berichte an die SED-Führung. Mit Online-Zugriff auf alle Berichte des Jahres 1989, Vandenhoeck \& Ruprecht, 2018. Wcześniejsze tomy dostępne są online: http://www.ddr-im-blick.de/Hubert_Co|BStUINTERNET/html/6050ivhfknvg_/S1018_600_ de_1328766017/MAINTAB\%5Etoc_sheet/_OLINK_TOC+CL+0 Należy również wskazać, że Stasi nie była jedyną instytucją zbierającą informacje na temat poglądów obywateli NRD. Robiły to również niektóre ministerstwa, organizacje gospodarcze, organizacje masowe, a także SED.

Literatura odnosząca się do historii BND jest bogata, przykładowo: A. Keßelring, Die Organisation Gehlen und die Verteidigung Westdeutschlands. Alte Elitedivisionen und neue Militärstrukturen, 1949-1953, Studie Nr. 3, Unabhängige Historikerkommission zur Erforschung der Geschichte des Bundesnachrichtendienstes1945-1968, red. J. Dülffer, K.D. Henke, W. Krieger, R.D. Müller, Phillips-Universität UHK/BND, Marburg 2014. http://www.uhk-bnd.de/wp-content/ uploads/2013/05/UHK-BND_Bd. 3_online.pdf (dostęp: 18 maja 2020); E. Schmidt-Eenboom, Schnüffler ohne Nase. Der BND - die unheimliche Macht im Staat, ECON Verlag, Düsseldorf 1993; ogólnie: J. Gawryszewski, Stużby specjalne w Republice Federalnej Niemiec, „Przegląd Bezpieczeństwa Wewnętrznego" 2012, nr 6/12, s. 11-23. 
a także materiały ze zbiorów GESIS - Leibniz-Institut für Sozialwissenschaften udostępnione online. Uzupełnienie stanowi literatura niemieckojęzyczna.

\section{Badania opinii publicznej w NRD i RFN}

Pierwszym instytutem badającym opinię publiczną i nastroje społeczne w NRD był powstały z inicjatywy Waltera Ulbrichta w 1964 roku Institut für Meinungsforschung beim ZK der SED - IfM (Instytut Badania Opinii Publicznej przy Komitecie Centralnym SED), na czele którego stanął Karl Maron, a od 1975 roku - Helene Berg ${ }^{4}$ Drugim ośrodkiem badania opinii publicznej stał się powstały jesienią 1966 roku Zentralinstitut für Jugendforschung - ZfJ (Centralny Instytut Badań nad Młodzieżą) z siedzibą w Lipsku, którego głównym zadaniem było prowadzenie badań wśród młodego pokolenia NRD. W założeniu obie placówki miały być instrumentami doradztwa politycznego. Jednak im bliżej były wglądu w rzeczywiste sytuacje i nastroje społeczne wśród obywateli, tym bardziej erupcjogenne stały się wyniki ich badań. Erich Honecker (w unii personalnej przewodniczący Rady Państwa NRD i Sekretarz Generalny SED) zirytowany analizami wskazującymi na odrzucenie, a wręcz uodpornienie się społeczeństwa na ideologię prezentowaną przez SED (Sozialistische Einheitspartei Deutschlands/Socjalistyczna Partia Jedności Niemiec) wydał w styczniu 1979 roku nakaz zamknięcia Instytutu i zniszczenia zgromadzonych tam danych empirycznych. Jak argumentowano, dalsze funkcjonowanie Instytutu mogłoby spowodować, że zebrane informacje trafiłyby w ręce ,wroga klasowego" ". Natomiast w 1980 roku Honecker wydał bezwzględny zakaz korzystania przez dziennikarzy z materiałów opracowanych przez wspomniany już wcześniej lipski Instytut Badań nad Młodzieżą ${ }^{6}$. Prowadzono w nim badania i dokonywano analiz aż do $1990 \mathrm{roku}^{7}$, chociaż na sam ośrodek nałożono częściowe restrykcje, np. zakaz publikacji niektórych wyników badań, a pracownikom utrudniano dostęp do szkół i innych instytucji. Dopiero po upadku NRD można było udostępnić pełny, obszerny zbiór danych instytutu ${ }^{8}$. Również w niniejszym opracowaniu przytoczone zostaną analizy ZfJ, z których korzystała nawet BND.

W RFN badanie opinii publicznej pod kątem preferencji politycznych ma tradycje sięgające 1945 roku. W październiku tego roku utworzona została w wydziale propagandy i cenzury amerykańskiej administracji wojskowej (Information Control Division) samodzielna sekcja badania opinii publicznej (Opinion Survey Section) pod kierunkiem Fredericka W. Williamsa, z siedzibą w Bad Homburg. W październiku i grudniu 1945

4 H. Niemann, Meinungsforschung in der DDR. Die geheimen Berichte des Instituts für Meinungsforschung an das Politbüro der SED, Bund-Verlag, Köln 1993, s. 34 i n.

5 A. Malycha, Die SED in der Ära Honecker. Machtstrukturen, Entscheidungsmechanismen und Konfliktfelder in der Staatspartei 1971 bis 1989, Oldenbourg Verlag, Berlin 2014, s. 91 i n.

6 Th. Bussemer, Propaganda: Konzepte und Theorien, Springer VS, Wiesbaden 2005, s. 230.

7 Das Zentralinstitut für Jugendforschung Leipzig 1966-1990, W. Fiedrich, P. Förster, K. Starke (red.), Edition Ost, Berlin 1999.

8 Längsschnittstudien aus der Jugendforschung der DDR. ZA-Information / Zentralarchiv für Empirische Sozialforschung, 39, s. 49-56, https://nbn-resolving.org/urn:nbn:de:0168-ssoar-200362 (dostęp: 5 maja 2020). 
roku zrealizowano pierwsze badania opinii publicznej w amerykańskiej strefie okupacyjnej (tzw. OMGUS-Surveys - Office of Military Government, United States). Uzyskane wyniki badań ilościowych miały poufny charakter i służyły nie tylko amerykańskiej administracji wojskowej, lecz także służbom cywilnym na najwyższym szczeblu. Prowadzono badania postaw Niemców, m.in. ich stosunek do władz okupacyjnych, denazyfikacji i demokratyzacji, w tym do reedukacji, a także ich ocenę narodowego socjalizmu i antysemityzmu9. Od 1947 roku pojawił się nowy element w badaniach - antykomunizm, a od roku 1949 badano stosunek obywateli do Ustawy Zasadniczej RFN ${ }^{10}$. W sumie do czerwca 1962 roku przeprowadzono w Niemczech Zachodnich ponad 200 badań ankietowych, które stanowiły podstawę ponad 500 raportów z badań ${ }^{11}$.

Od końca lat czterdziestych badania opinii publicznej stały się integralną częścią badań nad przemianami demokratycznymi, a także nad prawomocnością rządów politycznych w RFN i preferencjami politycznymi ${ }^{12}$. W obszarze zainteresowań badaczy niemieckich znalazło się także drugie państwo niemieckie i jego społeczeństwo. Pierwsze tego typu badania socjologiczne prowadzone były w RFN już na początku lat pięćdziesiątych na zlecenie Bundesministerium für gesamtdeutsche Fragen - BMG (Federalnego Ministerstwa do Spraw Ogólnoniemieckich). Badania przeprowadzone wśród robotników, którzy uciekli z NRD, miały ukazać stopień ich indoktrynacji komunistycznej, a także stosunek do własności prywatnej. Wyniki testów były bardzo interesujące i wskazywały jednoznacznie, że stalinizmowi nie udała się agitacja robotników. Jednocześnie stwierdzano, że większość z nich z sympatią odnosiła się do ideologii marksistowskiej: $35 \%$ badanych znajdowało się całkowicie lub w znacznym stopniu pod jej wpływem $26 \%$ częściowo prezentowało postawę promarksistowską, a jedynie $35 \%$ było von marxistischen Ideologie frei. Ponieważ coraz trudniej było prowadzić bezpośrednie sondaże wśród obywateli NRD, zdecydowano się na działania niestandardowe, jakimi były badania prowadzone przez Infratest z Monachium (Markt- und Meinungsforschungsinstitut München). Infratest już w drugiej połowie lat sześćdziesiątych. współpracował z BMG (od 1969 roku pod nazwą Federalne Ministerstwo Stosunków Wewnątrzniemieckich), przygotowując dla niego analizy typu Desk Research (chodziło wówczas o analizę zawartości prasy NRD). W 1968 roku Herbert Wehner, stojący wówczas na czele tego ministerstwa, zwrócił się do Instytutu z propozycją rozszerze-

\footnotetext{
$9 \quad$ Wyniki badań były niepokojące, zważywszy, że jeszcze w 1948 roku ponad 55\% badanych w amerykańskiej strefie okupacyjnej uważało, że narodowy socjalizm to dobra idea, ale źle wprowadzona w życie, a antysemityzm był ciągle jeszcze obecny w świadomości społecznej. E. Latzin, Lernen von Amerika?, Das US-Kulturaustauschprogramm für Bayern und seine Absolventen, Transatlantische Historische Studien, Bd. 23, Franz Steiner Verlag, Stuttgart 2005, s. 50; zob. również: U. Borsdorf, L. Niethammer (red.), Zwischen Befreiung und Besatzung. Analysen des US Geheimdienstes über Positionen und Strukturen deutscher Politik 1945, 2. wyd., Julius Beltz Athenaeum, Weinheim 1995, s. 315.

10 D. Fuchs, Die Unterstützung des politischen Systems der Bundesrepublik Deutschland, Springer VS, Wiesbaden 1989, s. 90.

11 Większość raportów OMGUS została opublikowana już w latach siedemdziesiątych XX wieku.

12 M. Kaase, Politische Meinungsforschung in der Bundesrepublik Deutschland, „Politische Vierteljahresschrift" t. 18, nr 2/3, Wahlsoziologie heute: Analysen aus Anlaß der Bundestagswahl 1976 (1977), s. 452-475.
} 
nia współpracy i przygotowania badań opinii publicznej, które odniosłyby się do sytuacji w NRD. Z powodów politycznych i technicznych nie można było prowadzić bezpośrednich wywiadów z obywatelami Niemiec Wschodnich - ani w miejscu ich zamieszkania, ani podczas ich odwiedzin w RFN, dlatego Infratest opracował model badań zastępczych łączących obserwację uczestniczącą $\mathrm{z}$ wywiadem pośrednim ${ }^{13}$. Grupą docelową byli zachodnioniemieccy obywatele, którzy w ostatnich dwóch miesiącach przynajmniej trzy dni spędzili w NRD ${ }^{14}$. Wywiady prowadzone były ustnie i składały się z dwóch części:

- w pierwszej respondent udzielał informacji na temat własnych spostrzeżeń nabytych podczas wizyty w NRD, a także mówił o sobie i swoich preferencjach politycznych, - druga odnosiła się do opinii czy też preferencji politycznych osoby X (obywatela NRD); ankietowany przekazywał informacje uzyskane w trakcie dłuższej rozmowy $\mathrm{z}$ osobą $\mathrm{X}$, co oznaczało, że był on jedynie pośrednikiem opinii (metoda wywiadu pośredniego).

Badania miały przybliżyć nastawienie polityczne i społeczne obywateli NRD, pokazać procesy tam zachodzące i określić szczególne wzorce zachowań, a także ich reakcje na bieżące wydarzenia w relacjach niemiecko-niemieckich. Efekty skomplikowanej interpretacji przyjmowały fizyczną formę pięciu egzemplarzy o statusie geheime Verschlusssache, które przekazywano do Federalnego Ministerstwa Stosunków Wewnątrzniemieckich; dwa z nich trafiały do Urzędu Kanclerskiego, jeden do senatu Berlina ${ }^{15}$. W 1989 roku przygotowano ostanie tego typu badania, kolejne zaś - w 1990 roku - prowadzone było już w innych warunkach i z wykorzystaniem nieco innej metodologii ${ }^{16}$. Od tego też roku wyniki badań zostały odtajnione i udostępnione badaczom ${ }^{17}$.

Kolejną instytucją zajmująca się aż do kwietnia 1990 roku badaniem opinii i nastrojów wśród obywateli NRD była BND ${ }^{18}$. Początki tych badań sięgały połowy lat osiem-

13 E. Holtmann, Volkes Stimme hinter der Mauer. Die westdeutschen „Stellvertreterumfragen” zum politischen und gesellschaftlichen Bewusstsein der Bevölkerung in der DDR, Bundeszentrale für politische Bildung, https://www.bpb.de/geschichte/zeitgeschichte/deutschlandarchiv/261037/ die-westdeutschen-stellvertreterumfragen (dostęp: 1 czerwca 2020).

14 Infratest prowadził również wywiady z osobami, które na stałe opuściły NRD. Więcej na ten temat zob. M. Meyen, Die Flüchtlingsbefragungen von Infratest. Eine Quelle für die Geschichte der frühen DDR, „Beiträge zur Geschichte der Arbeiterbewegung” 2000, R. 42, nr 4, s. 64-76.

15 E. Holtmann, A. Koehler, Wiedervereinigung vor dem Mauerfall. Einstellungen der Bevölkerung der DDR im Spiegel geheimer westlicher Meinungsumfragen, Bundeszentrale für politische Bildung, Bonn 2016, s. 31.

16 Sumaryczne wyniki badań z lat 1975-1989 dostępne są na stronie Statista. Umfrage zur Zufriedenheit der DDR-Bürger mit den politischen Verhältnissen 1975-89, https://de.statista.com/ statistik/daten/studie/408905/umfrage/umfrage-zur-zufriedenheit-der-ddr-buerger-mit-den-politischen-verhaeltnissen/.

17 Po odtajnieniu w 1990 roku wyników badań prowadzonych przez Infratest, dr Anne Köhler opublikowała w 1992 roku pierwszą krótką analizę wyników tych badań. Publikacja nosiła tytuł „Marschierte der DDR-Bürger im Geiste mit? Systemidentifikation der DDR-Bevölkerung vor und nach der Wende, w: U. Gerhardt, E. Mochmann (red.), Gesellschaftlicher Umbruch 1945-1990. Re-Demokratisierung und Lebensverhältnisse, Oldenbourg Verlag, München 1992, s. 59-79.

18 G. Piper, Abhörstaat Deutschland (Telepolis): Die SIGINT-Landschaft seit 1945 in Ost und West, Heise Zeitschriften Verlag, 2015, s. 1. 
dziesiątych i związane były nierozerwalnie z dwoma wydarzeniami z 1985 roku: dojściem do władzy Michaiła Gorbaczowa, a także mianowaniem Hansa-Georga Wiecka szefem BND. Już w 1984 roku Wick, jako ambasador RFN w Moskwie, był przekonany, że radziecka „koncepcja hegemoniczna w Europie Wschodniej [...] nie powiodła się" i że ZSRR będzie musiało pójść drogą reform ${ }^{19}$. Spostrzeżenia Wicka zdawały się znaleźć potwierdzenie w działaniach, które Gorbaczow rozpoczął zastępując radzieckiego ministra spraw zagranicznych Andrieja Gromyko pierwszym sekretarzem partii komunistycznej w Gruzji Eduardem Szewardnadze ${ }^{20}$. Aby przygotować się na ewentualne zmiany (w tym również w obszarze niemiecko-niemieckim) BND rozpoczęła od 1986 roku wzmożoną obserwację NRD, zaczynając od wywiadów z osobami, które albo przyjechały do RFN, np. w pilnych sprawach rodzinnych, lub wyjechały z NRD. Niedługo później przygotowano specjalne ankiety (600 sztuk), które poddawano analizie. Aby zwiększyć wartość informacyjną raportów, zdecydowano w 1988 roku o rozszerzeniu bazy informacyjnej o takie elementy jak:

- tło informacyjne i środowisko społeczne osób udzielających informacji, a także przyporządkowanie regionalne;

- struktura wiekowa respondentów: młodzież, np. młodzież pracująca, kręgi studenckie (wiek do ok. 25 lat), kręgi młodszego pokolenia, osoby pracujące zawodowo (ewentualnie z podaniem grupy wiekowej), emeryci;

- struktura społeczna: kręgi szkolne, klasa robotnicza, osoby o średnich kwalifikacjach zawodowych, osoby z wyższym wykształceniem / naukowcy, urzędnicy (średniego/wyższego szczebla), $\operatorname{kler}^{21}$.

Przewodnim celem nowego systemu prowadzenia ankiet było sprawdzenie, czy i w jakim stopniu obywatele NRD identyfikowali się ze swoim państwem. Na podstawie uzyskanych danych przygotowywano co sześć miesięcy raport. Prowadzonymi przez BND badaniami zainteresowanych były wiele wydziałów, które selekcjonowały zebrane informacje pod różnymi kątami. Odpowiadając na wzmożone zapotrzebowanie na informacje o NRD, zwrócono uwagę na istniejące już badania, analizy i sondaże, a także dane gromadzone przez instytucje państwowe NRD, które miały charakter reprezentatywny. Ich uwzględnienie w analizach BND zwiększało stabilność obrazu sytuacji w zakresie nastrojów panujących $\mathrm{w} \mathrm{NRD}^{22}$. W perspektywie długoterminowej pozwalało to na określenie długofalowych tendencji i zjawisk.

Już pierwsze wyniki osiągnięte dzięki zastosowaniu ankiety były nad wyraz ciekawe: od $72 \%$ do $78 \%$ wszystkich respondentów w 1986 roku pragnęło zjednoczenia Niemiec. Większość respondentów była gotowa na odrzucenie reżimu SED, choć nie można było stwierdzić u nich szczególnego entuzjazmu dla porządku demokratycznego. Ważną kwestią było utrzymanie świadomości ogólnoniemieckiej, czemu niewątpliwie

19 H.G. Wieck, Markierungen und Reflexionen, Bd. 1: Die Deutsche Frage, Books on Demand, Berlin 2013, s. 125 i n.

20 H. Wentker, Die DDR in den Angen des BND (1985-1990). Ein Interview mit Dr. Hans-Georg Wieck, „Vierteljahrshefte fur Zeitgeschichte” 2008, nr 2, s. 323-358.

21 Archiwum Federalne w Koblencji (BAK), B 206/570, Polityka wewnętrzna NRD, tutaj: Psychopolitische Lage in der DDR, 005/86 (Meinungsforschung), k. 107-117.

22 Ibidem. 
sprzyjało dążenie do uzyskania poziomu życia Niemców z zachodu ${ }^{23}$. Drugim ważnym punktem analizy była sytuacja gospodarcza NRD i poziom życia obywateli. W opracowanych przez zespół Wiecka kwestionariuszach pytano również o możliwości podróży i zamiarów przeniesienia się do RFN, a także o zakres odbioru mediów zachodnioniemieckich - gazet, radia i telewizji ${ }^{24}$. Celem było stwierdzenie nie tylko obiektywnych faktów, lecz także subiektywnej świadomości obywateli i ich poglądów co do trwałości istnienia NRD ${ }^{25}$. Dzięki ankietom i ich analizie odrzucono dotychczasowe oceny NRD oparte na rosnącej państwowości Niemiec Wschodnich, a także przekonanie, że jeszcze długo będą istnieć jako odrębne państwo. Wyniki systematycznie prowadzonych wywiadów jako „Raporty sytuacji psycho-politycznej” przesyłane były do odpowiednich ministerstw federalnych i komisji Bundestagu. Oprócz tego Wieckowi udało się przedstawić wyniki analiz kanclerzowi Helmutowi Kohlowi, który przyjął je z dużym zainteresowaniem, o czym świadczyć może fragment jego wspomnień, w których pisał o „tajnej ankiecie BND” i 80\% poparciu dla idei zjednoczenia wśród ankietowanych obywateli NRD. Podobnie reagował minister spraw zagranicznych Hans-Dietrich Genscher, a także członkowie komisji ds. niemiecko-niemieckich Bundestagu. Na uwagę zasługuje fakt, że o wynikach badań poinformowany został Detlew Kühn stojący na czele powołanego w 1969 roku Ogólnoniemieckiego Instytutu, który podlegał Federalnemu Ministerstwu Stosunków Wewnątrzniemieckich (Gesamtdeutsche Institut - Bundesanstalt für gesamtdeutsche Aufgaben). Do tego ministerstwa trafiały również analizy przygotowane przez Infratest, o czym mowa była już wcześniej. Oznacza to, że od połowy lat osiemdziesiątych XX wieku to ministerstwo dysponowało dwoma niezależnymi wynikami badań nastrojów społecznych w Niemczech Wschodnich i stosunku obywateli do idei zjednoczenia.

Tymczasem sytuacja zaczęła rozwijać się w tempie dotychczas niespotykanym. W 1989 roku doszło do znacznego uaktywnienia się opozycji w $\mathrm{NRD}^{26}$, czego wizualizacją było z jednej strony powstanie we wrześniu Nowego Forum, z drugiej zaś okrzyki obywateli NRD wołających w październiku 1989 roku do Gorbaczowa: Gorbi, hilf uns. Wznosząc je mieli na uwadze przede wszystkim wprowadzenie w kraju głębokich reform, w myśl hasła: Die Zeit ist reif ${ }^{7}$. Jedynie nieliczni myśleli wówczas o likwidacji NRD czy połączeniu z RFN. Jak wynika z dostępnych opracowań, praktycznie nikt nie

\footnotetext{
23 H. Wentker, Die DDR in den Augen... .

24 H.G. Wieck, DDR aus der Sicht der BND 1985-1990, w: H. Timmermann (red,) Die DDR in Europa: zwischen Isolation und Öffnung, Dokumente und Schriften der Europäischen Akademie Otzenhausen, Münster 2005, s. 191-207.

25 H. Wentker, Die DDR in den Augen... .

26 M. Lühmann, „Aufbruch 89 - NEUES FORUM”. Der Katalysator der friedlichen Revolution, w: Klatt J. \& Lorenz R. (red.), Manifeste: Geschichte und Gegenwart des politischen Appells, Transcript Verlag, Bielefeld 2010, s. 315-346. Dostęp online: www.jstor.org/stable/j.ctv1 fxfsm.14 (dostęp: 20 lipca 2020).

27 Jak wynika z opublikowanych przez BND materiałów, w RFN wiedziano o żądaniu Gorbaczowa i jego ultimatum wobec Honeckera. Gorbaczow ostrzegł, że Berlin mógł liczyć na wsparcie ZSRR tylko wtedy, „gdy będzie wykazywał większą demokrację i większą elastyczność”. 25 Jahre Mauerfall. Dokumente aus den Akten des BND, Mitteilungen der Forschungs- und Arbeitsgruppe „, Geschichte des BND”, Im Auftrag des Bundesnachrichtendienstes, Nr. 8, 2014, s. 52.
} 
liczył się z tym, że ZSRR zrezygnuje ze swojego przedpola, części swoistego cordon sanitaire, jakim była NRD. W tym miejscu należy przypomnieć, że również znaczna część opozycji wschodnioniemieckiej nie zakładała likwidacji państwa, bardziej stawiając na reformy i stworzenie socjalistycznego NRD ,z ludzką twarzą" ${ }^{28}$. Na pewno wzmocnieniem ruchów odśrodkowych było zapewnienie Moskwy o nieudzielaniu Berlinowi pomocy w opanowaniu sytuacji w kraju, a przede wszystkim w działaniach przeciwko protestującym ${ }^{29}$. W efekcie demonstracje, a szczególnie demonstracje poniedziałkowe w Dreźnie, nabrały impetu. W tym czasie pojawiły się również w sposób otwarty hasła wzywające do zjednoczenia Niemiec, co spowodowało, że aktualne stały się pytania: Co dalej? Dokąd zmierza NRD? Czy dojdzie do sytuacji, której obawiało się wielu obserwatorów życia politycznego, czyli powtórzenia zdarzeń z 1953 roku? ${ }^{30}$

\section{Stosunek obywateli NRD do zjednoczenia niemiecko-niemieckiego}

Kwestia stosunku obywateli NRD do zjednoczenia Niemiec pozostawała tematem eksplikacji od momentu podziału Niemiec na dwa państwa. W połowie lat siedemdziesiątych istniejący jeszcze wówczas Instytut für Meinungsforschung przeprowadził ściśle tajne badania na temat jedności Niemiec. BND nie zdołała wówczas pozyskać tych wyników, a jedynie ogólne informacje wskazujące, że rezultaty były wprawdzie dla SED niezadowalające, ale nie były skrajnie negatywne. Na początku 1985 roku BND weszła jednak w ich posiadanie i wówczas okazało się, że 50\% obywateli NRD utrzymywało w 1975 roku dobre relacje rodzinne z obywatelami RFN, co miało przełożenie na ich pozytywne stanowisko wobec idei zjednoczenia Niemiec. W niektórych środowiskach (głównie ludzi młodych) mocno występowano na rzecz jedności Niemiec, a nawet restytucji terenów utraconych na wschodzie ${ }^{31}$.

W analizie wytworzonej przez BND w styczniu 1986 roku wskazano, że zjednoczenie Niemiec nie było tematem dominującym, chociaż interesującym znaczną części obywateli NRD, podobnie jak inne tematy związane z relacjami niemiecko-niemieckimi. Sprzyjały temu rozwój techniki, polepszona jakość odbioru telewizji, a także możliwość oglądania takich samych programów (począwszy od rozrywki, aż po poważne debaty polityczne), jak członkowie rodziny czy znajomi z RFN ${ }^{32}$. To wzmacniało poczucie wspólnoty, a wiedza o wydarzeniach politycznych w RFN sprzyjała podnoszeniu takich

\footnotetext{
28 O postawie ówczesnych opozycjonistów pisze wielu autorów, m.in.: M. Sabrow, Mythos 1989, Bundeszentrake für politische Bildung, https://www.bpb.de/geschichte/zeitgeschichte/deutschlandarchiv/300737/mythos-1989; Mythos: „,Der Sozialismus ist eine gute Idee, die in der DDR nur schlecht ausgeführt wurde", Konrad-Adenauer-Stiftung, https://www.kas.de/de/web/ddr-mythos -und-wirklichkeit/sozialismus (dostęp: 20 lipca 2020).

29 W relacji BND pisano: „Gorbaczow nie był w stanie zachować starych struktur władzy w NRD”. 25 Jahre Mauerfall. Dokumente aus den Akten des BND, Mitteilungender Forschungsund Arbeitsgruppe ,, Geschichte des BND”..., Nr. 8, dok. 48, s. 52.

30 Ibidem.

31 BAK, B 206/573, k. 45-55, Psychopolitische Lage in der DDR (Stand: Januar 1986).

32 Michael Meyen jest zdania, że przeceniało się wpływ mediów RFN na społeczeństwo wschodnioniemieckie, o czym pisze w Kollektive Ausreise? Zur Reichsweite ost- und westdeutscher Fernsehprogramme in der DDR. „Publizistik” 2002, R. 47, nr 2, s. 200-220.
} 
tematów jak zjednoczenie czy obywatelstwo i to bynajmniej nie w interpretacji typowej dla $\mathrm{SED}^{33}$.

Ważną rolę w podtrzymaniu myśli o zjednoczeniu odegrało poczucie niemieckiej świadomości narodowej. Jak podkreślono w analizie BND, nie było innego pytania, które generowałyby tak jednoznaczną odpowiedz. Wir sind Deutsche ohne jede Einschränkung (,Jesteśmy Niemcami bez żadnych ograniczeń”) twierdzili wschodnioniemieccy respondenci ze wszystkich grup społecznych i wiekowych. Myśl o niemieckiej narodowości była głęboko zakorzeniona w świadomości i wzmacniana z jednej strony przez rzeczywisty i emocjonalny związek z narodem niemieckim, z drugiej zaś przez odrzucenie propagandowej tezy o DDR-Nation (,wschodnioniemieckiej narodowości” ${ }^{34}$ ). Byli też tacy, dla których była przejawem wewnętrznej emigracji. W efekcie nie wyrażali oni dumy z osiągnieć NRD, jednak w konfrontacji z innymi nacjami bloku wschodniego wykazywali rozbudowaną identyfikację z NRD. Przejawiało się to głównie w poczuciu i demonstracji wyższości podbudowanej osiągnięciami gospodarczymi, kulturalnymi i sportowymi Niemiec Wschodnich. Tę samokreację można było uznać za przejaw kompensacji potrzeb uznania i docenienia brakujących w relacjach z obywatelami RFN. Poczucie wspólnoty niemiecko-niemieckiej wzmacniali nieświadomie sąsiedzi NRD, którzy wskazywali na pracowitość i skuteczność działań występującą w obu państwach niemieckich jako na cechy typowe dla narodu niemieckiego ${ }^{35}$.

Zjednoczenie obu państw niemieckich było uważane przez większość społeczeństwa NRD za godną działania inicjatywę, ale absolutnie nie wierzono w szybką jego realizację. Zwłaszcza starsze pokolenie praktycznie zrezygnowało z tej myśli, natomiast dla pokolenia powojennego była ona wysoce abstrakcyjna. Stąd też koncentrowano się na idei jednej nacji i odrzuceniu koncepcji uznania obywatelstwa NRD (wprowadzonego 20 lutego 1967 roku). Nie wyobrażano sobie sytuacji, aby w RFN mieć status cudzoziemca składającego wniosek o azyl czy konkurować z innymi azylantami, np. z Trzeciego Świata ${ }^{36}$.

W BND prowadzono od 1986 roku nie tylko badania sytuacji społeczno-politycznej, poddawano także analizie wyniki sondaży realizowanych przez instytuty wschodnioniemieckie. W maju 1986 roku wywiad RFN uzyskał dane z sondażu na temat stosunku obywateli NRD do kwestii niemieckich i do idei zjednoczenia Niemiec ${ }^{37}$. W raporcie

33 BAK, B 206/573, k. 45-55, Psychopolitische Lage in der DDR (Stand: Januar 1986).

34 Po raz pierwszy teza o istnieniu dwóch narodowości niemieckich (socjalistyczna narodowość niemiecka i burżuazyjna narodowość niemiecka) wygłoszona została przez Waltera Ulbrichta w grudniu 1970 roku z okazji 25. rocznicy powstania SED. Była niejako odpowiedzią na słynną tezę Willy'ego Brandta o dwóch państwach i jednym narodzie. Więcej na ten temat: D.-K. Lee, Option oder Illusion?: Die Idee einer nationalen Konföderation im geteilten Deutschland, 1949-1990, Springer VS, Berlin 2010, s. 168-169.

35 BAK, B 206/573, k. 45-55, Psychopolitische Lage... .

36 Ibidem; Co ciekawe negatywne nastawienie obywateli NRD do azylantów, a także imigrantów pochodzenia niemieckiego (wysiedleńców z Europy Środkowej i Wschodniej) odnotowano również w maju 1989 roku. Ich stosunek do tych ludzi nacechowany był przede wszystkim zazdrością o świadczenia socjalne. Widoczne było również rozczarowanie wobec polityki migracyjnej prowadzonej przez RFN. BAK, B 206/574, k. 152, Die Einwanderungspraxis der Bundesrepublik Deutschland im Meinungsbild, 22. Mai 1989.

37 BAK, B 206/573, k. 35-44, Psychopolitische Lage in der DDR, 28. Juli 1986. 
z 28 lipca 1986 roku przywołano te wyniki, porównując je z opracowanymi przez BND danymi. Znaczna ich część, w tym również zagadnienie stosunku obywateli wschodnioniemieckich do RFN (poczucie wspólnoty narodowej - RFN to nie zagranica), nie odbiegała wartościami od wyników analizy wywiadu wschodnioniemieckiego. W niektórych obszarach, np. stosunku do idei zjednoczenia Niemiec, odnotowano niewielkie różnice. Przykładowo, badania wykonane na zlecenie SED wskazywały, że zjednoczenie było traktowane przez obywateli NRD jako utopia, ale wyobrażano sobie możliwość kooperacji między oboma państwami niemieckimi. Z tą tezą konkurowały obawy związane z niemożnością odnalezienia się w systemie kapitalistycznym czy koniecznością rywalizacji wolnorynkowej. Te niepokoje, a także gwarantowane w systemie socjalistycznym świadczenia i miejsca pracy hamowały odwagę do zmian, jednocześnie dopuszczając równoległe istnienie różnych systemów gospodarki. W analizie BND wskazano podobnie: wśród obywateli NRD była obecna myśl o zjednoczeniu z równoczesnym brakiem wiary w jej realizację, a także jej tabuizację w rozmowach. Niemniej jednak obywatele NRD porównywali oba systemy społeczno-gospodarcze, powątpiewając w możliwość odnalezienia się w zachodnim systemie społecznym. Poza tym obawiano się, że w RFN nie była szczególnie obecna wola zjednoczenia. Do tego dochodziły spore trudności z realną oceną stosunków społecznych panujących w RFN, a zwłaszcza kwestii opieki socjalnej ${ }^{38}$. Z analizy przygotowanej przez BND wynikało, że jedynie $50 \%$ obywateli NRD było gotowych zaakceptować zjednoczenie z zachowaniem zachodnich realiów społecznych i socjalnych. Takiego właśnie zdania były kręgi akademickie $^{39}$. Również w następnych badaniach sondażowych prowadzonych zarówno na zlecenie SED, jak i w BND nie zmieniły się zasadnicze spostrzeżenia na temat myśli zjednoczeniowej - obecnej, ale w abstrakcyjnej formie ${ }^{40}$.

Nieco więcej informacji o podejściu obywateli NRD do idei zjednoczenia Niemiec uzyskano z sondaży przeprowadzonych w pierwszej połowie 1988 roku na zlecenie struktur rządowych i partyjnych przez Instytut Polityki Międzynarodowej i Gospodarki (Institut für Internationale Politik und Wirtschaft in Berlin (Ost)). Opracowania zostały przechwycone przez BND i trafiły do najważniejszych odbiorców tego typu informacji w RFN, w tym również na biurko kanclerza federalnego ${ }^{41}$. Wyniki badań potwierdziły dotychczasowe trendy odnoszące się do powiązań osobistych i ideowych z RFN, poczucia niemieckiej wspólnoty, a także występującej powszechnie myśli o zjednoczeniu (bez nadziei na jej realizację również w wymiarze politycznym). Pojawiły się równocześnie nowe elementy takie jak obawy niektórych grup społecznych przed utratą przywilejów socjalnych. Wskazano również na negatywne pierwiastki zachodnioniemieckiego sys-

38 Bon mot: „Lieber der ärmste Arbeitslose in der BRD, als ein »Held der Arbeit« in der DDR”; Wyniki badań długookresowych wśród przesiedleńców z NRD w kontekście ich bezrobocia w RFN przedstawili A., Hahn i R. Schwarzer, Streß, soziale Unterstützung und Gesundheit nach Arbeitsplatzverlust: Eine Längsschnittstudie zur Wiedereingliederung von DDR- Übersiedlern in das Arbeitsleben, w: T. Kieselbach (red.), Arbeitslosigkeit und Gesundheit-Neuere Ergebnisse der europäischen Arbeitslosigkeitsforschung, Deutscher Studien Verlag, Weinheim 1996, s. 120-143.

39 BAK, B 206/573, k. 35-44, Psychopolitische Lage in der DDR, 28. Juli 1986, k. 41-42.

40 BAK, B 206/573, k. 31-34, Psychopolitische Lage in der DDR (Ergänzung, Stand: März 1987).

41 BAK, B 206/573, k. 20-23, DDR - Innenpolitik, hier: Studie zur Haltung der DDR-Bevölkerung zur Wiedervereinigung, 16. September 1988. 
temu społecznego: bezrobocie, dystans społeczny i samotność, które dominowały nad pokusą społeczeństwa konsumpcyjnego ${ }^{42}$. Badacze z NRD wyodrębnili trzy grupy społeczne, uwzględniając ich stosunek do zjednoczenia niemiecko-niemieckiego:

1. Niższa warstwa społeczna (einfache Bevölkerungsschicht) jest zasadniczo otwarta na ideę zjednoczenia, które oznacza dla tej grupy nadzieję na polepszenie standardu życia i nieograniczoną swobodę. Perspektywa udziału w dobrobycie RFN wypierała obawy związane z możliwymi problemami socjalnymi czy niepewnością rodzinną.

2. Klasy wyższe (gehobene Schichten) w zasadzie popierały ideę zjednoczenia, ale pragnęłyby takiego modelu, który integrowałby korzyści systemu kapitalistycznego z istniejącym systemem społecznym NRD. Niechętnie myślano o ewentualnych ustępstwach czy niekorzystnych rozwiązaniach osobistych związanych ze zjednoczeniem.

3. Znaczną różnicę stosunku do zjednoczenia odnotowano w grupie wyższych urzędników i części inteligencji. Ich opinie oscylowały między jednoznacznym odrzuceniem idei zjednoczenia z powodów społeczno-politycznych lub ideologicznych, a ich zgodą głównie z powodów ekonomicznych. W tej grupie prawie nie występowały konkretne argumenty ,za” lub ,przeciw”, nierzadko posługiwano się banałami propagandowymi lub oportunistycznymi argumentami ${ }^{43}$.

W dokumencie BND poddano pod rozwagę jeden z wyników sondaży wskazujący, że w grupie osób pracujących ok. 10\% opowiedziało się jednoznacznie przeciwko niemiecko-niemieckiemu zjednoczeniu. Drugą kwestią, na którą zwrócono uwagę w BND, było występujące u większości obywateli wschodnioniemieckich przekonanie, że Gorbaczow - w odróżnieniu od władz partyjnych i państwowych NRD - nie był negatywnie nastawiony do idei zjednoczenia obu państw niemieckich ${ }^{44}$. Ewolucji stanowiska władz NRD w tej kwestii oczekiwano dopiero po zmianach generacyjnych ${ }^{45}$.

Wraz z zaostrzeniem się sytuacji w NRD i narastającą falą protestów coraz bardziej aktualne stało się pytanie o stosunek Niemców z Niemiec Wschodnich do idei zjednoczenia niemiecko-niemieckiego. Tego typu sondaże prowadzone były zarówno w NRD, jak i w RFN, chociaż przy tak znacznej dynamice zdarzeń wyniki prowadzonych badań mogły być zaledwie w ciągu kilku dni zdezaktualizowane. Charakterystyczną cechą

\section{Ibidem.}

43 Ibidem.

44 W czerwcu 1989 roku przy okazji wizyty Michaiła Gorbaczowa w RFN przeprowadzono tam sondaż na temat wpływu polityki radzieckiego sekretarza na relacje niemiecko-niemieckie. Na pytanie, czy polityka Gorbaczowa zwiększy prawdopodobieństwo zjednoczenia dwóch państw niemieckich, 40,7\% ankietowanych odpowiedziało twierdząco, a tylko 1,5\% uważało, że stanie się to mniej prawdopodobne, 55,8\% zakładało, że nic się nie zmieni. B. Szummi, I. Lichtleitner, F. Bauske, Datenreport: Die Vereinigung der beiden deutschen Staaten. „ZAInformation / Zentralarchiv für Empirische Sozialforschung" 1990, nr 26, s. 69-70, https://nbn-resolving.org/urn:nbn:de:0168-ssoar-202589 (22 czerwca 2020).

45 BAK, B 206/573, k. 20-23, DDR - Innenpolitik, hier: Studie zur Haltung der DDR-Bevölkerung zur Wiedervereinigung, 16. September 1988; w 1989 roku w BND wiedziano od dawna o bardzo chłodnych relacjach Gorbaczowa i Honeckera, a także o ich rozmowie w cztery oczy, z której Honecker miał wyjść w szoku. Mówiono, że Gorbaczow wezwał go do dymisji, a także odmówił jakiegokolwiek wsparcia dla SED. BAK, B 206/587, Betr: Innenpolitische Situation in der DDR, hier: Sprechzettel für PKK-Sitzung, 3. November 1989, k. 53-58. 
dostępnych analiz sytuacji psycho-politycznej BND był ich syntetyczny charakter określały ogólne nastroje i trendy ${ }^{46}$, rzadziej podawano konkretne dane procentowe, chociaż sięgano do niektórych wyników sondaży prowadzonych przez $\mathrm{ZfJ}{ }^{47}$. W celu analizy postawy społeczeństwa enerdowskiego wobec idei zjednoczenia (a także stosunku do przesiedleń, o czym mowa będzie w dalszej części tekstu) w okresie od jesieni 1989 roku do wiosny 1990 roku znacznie dokładniejsze pod względem kwantytatywnym są wyniki sondaży realizowanych przez ZfJ. W tym kontekście należy wskazać na trzyczęściową serię badań prowadzonych pod koniec listopada 1989, w lutym 1990 i w połowie marca 1990 roku (przed wyborami), czyli w okresie „politycznego wakuum” ${ }^{\prime 4}$.

Wyniki sondaży wskazywały, że pod koniec listopada 1989 roku $48 \%$ respondentów opowiadało się za zjednoczeniem niemiecko-niemieckim (16\% - zdecydowanie, a 32\% - raczej było za zjednoczeniem), przeciwnych zjednoczeniu było 52\% (raczej przeciwnych $29 \%$; zdecydowanie przeciwnych $23 \%$ ). W następnych badaniach z przełomu stycznia i lutego 1990 roku już 79\% obywateli NRD było zwolennikami zjednoczenia (w wymiarze szczegółowym było to odpowiednio $40 \%$ i 39\%), przeciwnikami było zaledwie $21 \%$ (odpowiednio: $15 \%$ i $6 \%$ ). Ostatnia część tych badań wykazała, że $84 \%$ opowiadało się za zjednoczeniem (odpowiednio: 43\% i 41\% ), przeciwko było $16 \%$ (odpowiednio 13\% i 3\% ). Ciekawie przedstawiał się podział głosów w ujęciu grup społecznych: wśród robotników zwolennikami zjednoczenia było w listopadzie 1989 roku $48 \%$, w drugim sondażu $80 \%$ było za, a w trzecim $87 \%$. Nieco inaczej kształtowało się poparcie dla zjednoczenia wśród urzędników: w pierwszym badaniu $38 \%$ było za, w drugim 79\% i trzecim $83 \% \mathrm{~W}$ tym miejscu należy wskazać, że w tej grupie społecznej było najwięcej wskazań zdecydowanego sprzeciwu (sehr dagegen) wobec planów zjednoczenia: w listopadzie było to $32 \%$ - o 10 punktów procentowych więcej niż w pozostałych grupach. W kolejnych badaniach było to odpowiednio $7 \%$ i $2 \%$. Na uwagę zasługuje fakt, że ostatnia wartość była najniższa spośród wszystkich grup. Bardzo negatywne nastawienie do zjednoczenia tej grupy zmniejszyło się w przeciągu 3,5 miesiąca o 30 punktów procentowych. Wśród rencistów występowało w listopadzie 1989 roku największe poparcie dla idei zjednoczenia - 53\%, w kolejnych badaniach poparcie

46 W analizie przygotowanej pod koniec sierpnia potwierdzono trendy występujące już wcześniej wśród obywateli NRD: wysoką świadomość wspólnoty narodowej, chociaż podzielonej pod względem państwowym, a także łączność osobistą i ideową z RFN bardziej wyrazistą, niż wynikało to z ocen władz NRD, czemu sprzyjała intensywna ,konsumpcja” mediów z Berlina Zachodniego. BAK, B 206/587, k. 76-86, Entwicklung in der DDR, 1. September 1989.

47 BAK, B 206/570, k. 107-117, Innenpolitische Lage DDR, tutaj: Psychopolitische Lage in der DDR, 005/86 (Meinungsforschung).

48 Zentralinstitut für Jugendforschung (dalej: ZfJ), (mit Unterstützung des Instituts für Marktforschung), Ergebnisse der DDR-repräsentativen Meinungsumfrage M 3, Leipzig, April 1990, s. 16 -17, https://nbn-resolving.org/urn:nbn:de:0168-ssoar-4045; W tym czasie nastąpił szybki proces rozpadu struktur państwowych (grożący chaosem), co było przyczyną przyśpieszenia wyborów do Izby Ludowej. BAK, B 206/535, k. 273, Beitrag zur ND-Lage, Betr: DDR - Aspekte zur aktuellen Situation hinsichtlich der Wahlen zur Volkskammer am 18. Marz., 5. Februar 1990; W analizach BND wskazywano również na skłócenie wewnętrzne opozycji, co nie sprzyjało wychodzeniu z chaosu, BAK, B 206/587, k. 2-5, Beitrag zur ND-Lage, Betr.: DDR: Aktuelle innenpolitische Situation, 8. Januar 1990, k. 4. 
wzrastało odpowiednio do $78 \%$ i $81 \%$ - co było jednak najniższym poparciem w grupach badanych w marcu 1990 roku. Równocześnie ujawniła się w tej grupie tendencja do zdecydowanie negatywnej oceny procesu zjednoczenia: było to odpowiednio $7 \%$ i $4 \%{ }^{49}$.

Badania, jakie prowadził ZfJ, pozwalają ukazać poparcie dla procesu zjednoczenia również w rozbiciu na płeć (w tym wypadku dane sięgają do połowy sierpnia 1990 roku) i na grupy wiekowe. I tak w listopadzie 1989 roku 48\% kobiet i 44\% mężczyzn było za zjednoczeniem oraz odpowiednio 52\% i 56\% przeciwko; w lutym 1990 roku wskaźnik ten wynosił: $76 \%$ i $82 \%$ za zjednoczeniem oraz odpowiednio $24 \%$ i $18 \%$ przeciwko zjednoczeniu. W marcu $82 \%$ kobiet i $88 \%$ mężczyzn, a w kwietniu $80 \%$ kobiet i 92\% mężczyzn było za zjednoczeniem niemiecko-niemieckim; w czerwcu poziom poparcia dla zjednoczenia wynosił $81 \%$ wśród kobiet i $87 \%$ wśród mężczyzn, a w połowie sierpnia poparcie wzrosło do $88 \%$ wśród kobiet i $93 \%$ wśród mężczyzn ${ }^{50}$. Badania pokazały zmiany trendu $\mathrm{w}$ akceptacji zjednoczenia w grupie kobiet: od większej w listopadzie 1989 roku (optymizm przemian?), po jej spadek w sierpniu 1990 roku, zwłaszcza w porównaniu do mężczyzn. Proces ten mógł być sygnałem, że kobiety bardziej odczuwały zagrożenia związane z przekształceniami zachodzącymi w NRD.

W listopadzie 1989 roku idea zjednoczenia cieszyła się poparciem wśród 39\% uczniów, 20\% studentów i 35\% uczniów szkół zawodowych. W sumie wśród osób w grupie wiekowej 15-24 lata, 34\% było zwolennikami zjednoczenia. Na przełomie stycznia i lutego 1990 roku 72\% uczniów, 63\% studentów i 74\% uczniów zawodu popierało zjednoczenie, co łącznie dawało 78\% poparcia w grupie wiekowej 15-24 lata, w połowie marca 1990 roku było to $80 \%$.

Wśród osób całkowicie identyfikujących się z NRD na przełomie stycznia i lutego 1990 roku $20 \%$ opowiadało się w sposób zdecydowany za zjednoczeniem, $45 \%$ było raczej za zjednoczeniem, $25 \%$ - raczej przeciw i 10\% - zdecydowanie przeciw. W grupie identyfikującej się w sposób ograniczony z NRD poparcie dla zjednoczenia kształtowało się odpowiednio: $47 \%, 44 \%, 7 \%$ i $2 \%$. Osoby, które w niewielkim stopniu identyfikowały się z NRD, w $73 \%$ zdecydowanie popierały zjednoczenie i w $26 \%$ raczej popierały. Praktycznie w tej grupie nie było sprzeciwu wobec zjednoczenia niemiecko-niemieckiego. Podobnie było wśród osób, które nie identyfikowały się z NRD - 91\% było zdecydowanie za zjednoczeniem ${ }^{51}$.

Kolejnym sondowanym zagadnieniem był stosunek obywateli NRD do tempa zjednoczenia. To pytanie pojawiło się po raz pierwszy w ankiecie na przełomie stycznia i lutego 1990 roku i miało związek z wystąpieniami kanclerza Helmuta Kohla i zapowiedzią zainicjowania szybkiego procesu zjednoczenia. Zwolennikami natychmiastowego zjednoczenia było wówczas $39 \%$ badanych, $41 \%$ było temu przeciwnych, zdania na ten temat nie miało $20 \%$ ankietowanych. Wśród zwolenników bezzwłocznego zjednoczenia znajdowało się $41 \%$ mężczyzn i 37\% kobiet, a także 32\% uczniów, 20\% studentów i $31 \%$

\footnotetext{
49 ZfJ, Ergebnisse der DDR-repräsentativen Meinungsumfrage M 3...

50 U. Schlegel, Junge Frauen in der DDR 1990: Befindlichkeiten zwischen bisheriger Biographie und Zukunft: Zusatzbericht zu den Meinungsumfragen von Sept. 89-Sept. 90.. Leipzig 1990, Zentralinstitut für Jugendforschung (ZfJ). https://nbn-resolving.org/urn:nbn:de:0168-ssoar-404587 51 ZfJ, Ergebnisse der DDR-repräsentativen Meinungsumfrage M 2: Kurzbericht 1990, Leipzig, https://nbn-resolving.org/urn:nbn:de:0168-ssoar-403841 (dostęp: 6 maja 2020).
} 
uczniów zawodu. Wśród osób w grupie wiekowej 25-34 lata natychmiastowego zjednoczenia chciało $36 \%$ respondentów, w grupie wiekowej $35-44$ lata było to $41 \%$, a grupie wiekowej $45-54$ lata - 43\%. Wśród osób powyżej 55 lat 41\% opowiadało się za natychmiastowym zjednoczeniem. W kolejnym sondażu przeprowadzonym w połowie marca 1990 roku niemalże połowa respondentów (48\%) opowiadała się za bezzwłocznym zjednoczeniem. Zwolennikami szybkiego zjednoczenia było 50\% mężczyzn i $46 \%$ kobiet. Zarówno wśród robotników, jak i urzędników oraz rencistów wzrosło poparcie dla szybkiego zjednoczenia. Za tym modelem opowiedziało się odpowiednio $53 \%$, 44\%, i $49 \%$ ankietowanych, przy czym $25 \%$ rencistów nie miało wyrobionego zdania na ten temat (wśród robotników i urzędników wskaźnik ten był mniejszy i wynosił $16 \%, 18 \%)^{52}$.

Równie interesujące było pytanie o drogę, jaką miały podążyć zjednoczone Niemcy. Czy miały być państwem, w którym wartości humanistyczne realizowałby zreformowany socjalizm, czy państwem o kapitalistycznym systemie społeczno-politycznym, a może powinny podążać trzecią, pośrednią drogą - stworzyć konfederację, czyli bliski związek NRD i RFN z równoczesną niezależnością polityczną? Według danych ZfJ w listopadzie 1989 roku 89,1\% obywateli NRD opowiadało się za zreformowanym socjalizmem, zaledwie $3,4 \%$ za drogą kapitalistyczną, a 7,5\% optowało za trzecim rozwiązaniem - konfederacją ${ }^{53}$. Natomiast instytut wyborczy Infas ogłosił w grudniu 1989 roku, że 46\% obywateli NRD chce „systemu mieszanego" (trzecia droga). Tylko $26 \%$ opowiedziało się za wprowadzeniem w NRD systemu gospodarki rynkowej (system kapitalistyczny), $21 \%$ chciało urzeczywistnić „demokratyczny socjalizm" ${ }^{4}$. Te dane korespondowały z informacjami BND, według których „system kapitalistyczny” budził z punktu widzenia ideologicznego obawy. Większość obywateli życzyła sobie systemu gospodarczego typu zachodniego z silnym komponentem socjalnym ${ }^{55}$. Natomiast w kolejnym sondażu reprezentatywnym przeprowadzonym przez ZfJ (przełom stycznia i lutego 1990 roku) $34 \%$ ankietowanych opowiedziało się za systemem kapitalistycznym, $54 \%$ za konfederacją i $12 \%$ za zreformowanym socjalizmem ${ }^{56}$.

\section{Problem migracji z NRD}

Kolejne pytanie, które determinowało zarówno politykę NRD, jak i RFN, dotyczyło migracji ze wschodnich do zachodnich Niemiec. Przez wiele lat kwestia ta kształtowała w znacznym stopniu wzajemne relacje obejmujące m.in. problemy ucieczek z NRD, wykupowania więźniów politycznych i działaczy opozycyjnych ${ }^{57}$ czy warunków i za-

\footnotetext{
52 ZfJ, Ergebnisse der DDR-repräsentativen Meinungsumfrage M $3 \ldots$

53 ZfJ $S$ 6018, Meinungsumfrage November 1989...

54 M. Glaab, Deutsche Einheit in der Retrospektive. Befindlichkeiten in Ost und West, 2009, https://www.cap-lmu.de/aktuell/positionen/2009/deutsche-einheit.php (dostęp: 6 maja 2020).

55 B 206/594, Betr: Fragen über die neuesten Entwicklung in der DDR, 14. Dezember 1989.

56 ZfJ, Ergebnisse der DDR-repräsentativen Meinungsumfrage $M 2 \ldots$

57 Republika Federalna zapłaciła w latach 1966-1989 ponad 3,5 mld marek za uwolnienie 33755 więźniów z NRD. Berlin Wschodni naliczał początkowo 40 tys. DM za jednego więźnia, w 1977 roku kwota wzrosła do 95847 DM. Często byli to ludzie skazani za ,próbę ucieczki z Republiki”. H. Jenkis, Der Freikauf von DDR-Häftlingen. Der deutsch-deutsche Menschenhandel, Zeitgeschichtliche Forschungen (ZGF), t. 45, Duncker \& Humblot, Berlin 2012.
} 
sad przesiedlenia się (legalnej migracji). Bez wątpienia dla władz NRD zjawisko miało znaczenie nie tylko praktyczne - zmniejszająca się liczba siły roboczej, lecz przede wszystkim wizerunkowe (w latach 1949-1989 liczba ludności w NRD spadła z 19,1 do $16,4 \mathrm{mln})^{58}$. Na początku 1989 roku, próbując zmniejszyć pragnienie wyjazdu do RFN, wprowadzono szereg działań, które miały na celu obniżenie liczby wniosków ${ }^{59}$, np.: naciski na osoby składające wniosek o przesiedlenie, podniesienie wynagrodzeń w wielu grupach zawodowych, a wreszcie zwiększenie liczby wyjazdów krótkoterminowych (Honecker zapowiedział, że w 1989 roku 7 mln turystów będzie mogło odwiedzić RFN) ${ }^{60}$. Wprowadzono również możliwość podróży na zachód w przypadkach humanitarnych czy towarzyszenie $\mathrm{w}$ podróży osobom ciężko chorym i ułomnym, co było wypełnieniem zobowiązań KBWE, jakie przyjął na siebie Berlin Wschodni. BND oceniała, że wśród odwiedzających RFN było ok. 1,2-1,3 mln osób w wieku produkcyjnym. Ich wizyty sprawiały, że młodzi ludzie szczególnie żywo reagowali na różnicę w standardzie życia w RFN i NRD, co z kolei wpływało na ich krytyczny stosunek do marksizmu-leninizmu i SED, czemu również sprzyjała znaczna sympatia dla Gorbaczowa i jego działań reformistycznych, popularnych w społeczeństwie NRD ${ }^{61}$. Powszechna gotowość opuszczenia wschodnich Niemiec odzwierciedlały liczby, chociaż niektóre $\mathrm{z}$ nich były ściśle chronioną tajemnicą, jak np. wielość złożonych wniosków o przesiedlenie do RFN. W BND oceniano, że na początku 1989 roku było ich około miliona. Do końca sierpnia 1989 roku 55 tys. obywateli NRD uzyskało zgodę na przesiedlenie się do $\mathrm{RFN}^{62}$. Były również osoby nielegalnie przekraczające granicę niemiecko-niemiecką: w 1987 roku 6252 osoby, w 1988 roku - już 9705 osób (dane oficjalne) ${ }^{63}$.

Masowe ucieczki, do których dochodziło od lata 1989 roku (głównie przez Budapeszt, Pragę i Warszawę), były wyrazem powszechnie widocznego poczucia rezygnacji i braku perspektyw ${ }^{64}$. Oficjalne otwarcie granicy węgiersko-austriackiej 11 września 1989 roku o północy umożliwiło jej przekroczenie przez 21 tys. uchodźców. Do tej

58 Emigracja była głównym problemem w NRD: między ustanowieniem państwa w 1949 roku, a podczas budowy muru w 1961 roku uciekło do RFN od 2,6 do 3,6 mln osób (jednocześnie ok. 500 tys. osób z RFN przeprowadziło się do NRD). W 1961 roku zamknięto granice murem, niemniej jednak ponad 600 tys. obywateli zdołało opuścić NRD. K. Bade, J. Oltmer, Migration, Ausländerbeschäftigung und Asylpolitik in der DDR, Bundeszentrale für politische Bildung, https://www. bpb.de/gesellschaft/migration/dossier-migration-ALT/56368/migrationspolitik-in-der-ddr?p=all (dostęp: 27 maja 2020).

59 BAK, B 206/587, k. 87-94, Entwicklung in der DDR, 21. April 1989.

60 Ibidem, k. 90.

61 Ibidem, k. 89.

62 BAK, B 206/594, k. 66-76, Entwicklung in der DDR, 01. September 1989.

63 Liczba ta obejmuje wszystkie osoby, które nielegalnie opuściły NRD, np. osoby, które nie wróciły po odbytej oficjalnie wizycie w RFN; osoby, które wyjechały do RFN za pośrednictwem tranzytu czy w końcu osoby, które nielegalnie przekroczyły granicę, np. czechosłowacko-bawarską: w 1987 roku było to 288 osób, w roku 1988 - 590 osób. W 1988 roku odnotowano 281 nieudanych przekroczeń granicy czesko-bawarskiej. BAK, B 206/587, k. 87-94, Entwicklung in der DDR...

${ }_{64} \mathrm{Na}$ temat masowych ucieczek z NRD ukazało się wiele publikacji, m.in.: Sommer 1989: Die große Flucht aus der DDR, lipiec 2019, https://www.bpb.de/politik/hintergrund-aktuell/293568/ddr -ausreisewelle; W. Mayer, Flucht und Ausreise. Botschaftsbesetzungen als wirksame Form des Widerstands und Mittel gegen die politische Verfolgung in der DDR, Anita Tykve Verlag, Berlin 2002. 
liczby należało dodać osoby legalnie opuszczające NRD (60 tys.), a także 37 tys. tych, którzy zrobili to nielegalnie ${ }^{65}$. W 1989 roku nasiliła się chęć wyjazdu ze wschodnich Niemiec: na początku 1989 roku było to około 6-7\%, we wrześniu 1989 roku liczba ta wzrosła do ok. $10 \%$, czyli 1,6-1,7 mln obywateli66. Jak obliczono w BND, do 4 października 1989 roku z NRD wyjechało ok. 125 tys. osób, w tym 65 tys. jako przesiedleńcy, 13 tys. - to osoby pozostałe za granicą przy okazji legalnych wyjazdów krótkoterminowych, 1 tys. nielegalne przekroczył granicę niemiecko-niemiecką i 46 tys. uciekło za pośrednictwem ambasad RFN w Pradze i w Warszawie ${ }^{67}$. Dynamika wyjazdów znacznie wrosła: tydzień później liczba obywateli NRD, którzy przekroczyli granicę RFN, zwiększyła się o 5 tys ${ }^{68}$ Według danych BND z 5 listopada 1989 roku do RFN przybyło w tym roku 165 tys. obywateli $\mathrm{NRD}^{69}$. Należało się spodziewać dalszych przyjazdów, jako że podczas demonstracji pojawiły się hasła żądające wolności podróży (Die Mauer muss weg) ${ }^{70}$. Na początku października 1989 roku w BND liczono się z zaostrzeniem konfliktu w NRD z uwagi na działania mające na celu utrzymanie kontroli nad sytuacją w kraju i ograniczenie wystąpień ${ }^{71}$. Oceniano, że organy porządkowe mogły podjąć radykalne działania, bez względu na możliwość utraty reputacji międzynarodowej ${ }^{72}$. Wbrew obawom, prognozy nie potwierdziły się, a nawet doszło do diametralnej zmiany nastrojów i wzmożonej aktywności mieszkańców, co wykazały kolejne analizy sytuacji wewnętrznej w NRD. W analizie BND z końca października 1989 roku ukazano zmiany nastrojów: od rezygnacji, apatii, poprzez radość z ucieczek i faktu, że niektórym się udało, a także, że „tym na górze uciekali ludzie” (Schadenfreude), aż do złości wywołanej obawami o los kraju ${ }^{73}$. Jak wynika z badań ZfJ, prawie połowa obywateli NRD wyrażała w listopadzie 1989 roku zrozumienie dla decyzji o wyjeździe z kraju ${ }^{74}$. Nastroje społeczne w NRD ewoluowały w kierunku wzburzenia, gniewu

${ }_{65}$ BAK, B 206/587, k. 70-75, Betr.: PKK-Sitzung am 27. September 1989, hier: DDR, 26. September 1989, k. 74.

66 Ibidem, k. 75.

67 BAK, B 206/587, k. 65-69, Betr.: Entwicklung in der DDR (Fortschreibung vom 26. September 89), 4. Oktober 1989, k. 66.

68 BAK, B 206/587, k. 59-64, Betr.: Entwicklung in der DDR, 09. Oktober 1989, k. 60.

69 BAK, B 206/587, k. 53-58, Betr.: Innenpolitische Situation in der DDR, hier: Sprechzettel für PKK-Sitzung, 09. November 1989, k. 57.

70 Dynamikę przesiedleń z NRD do RFN prezentuję na podstawie danych Federalnego Ministerstwa Spraw Wewnętrznych. A. Hahn, Geschichte und Szenarien der Übersiedlung, w: R. Schwarzer, M. Jerusalem (red.), Gesellschaftlicher Umbruch als kritisches Lebensereignis. Psychosoziale Krisenbewältigung von Übersiedlern und Ostdeutschen, Juventa, Weinheim-München 1994, s. 23-48. 71 BAK, B 206/587, k. 65-69, Betr.: Entwicklung in der DDR..., k. 67; Die Chronik der Ereignisse vom 1. Januar 1989 bis zum 3. Oktober 1990, Presse- und Informationsamt der Bundesregierung, Oktober 2016.

72 BAK, B 206/587, k. 59-64, Betr.: Entwicklung in der DDR, 09. Oktober 1989, k. 61.

73 BAK, B 206/573, k. 102-105, DDR-Innenpolitik, hier: Stimmungswandel in der DDR Bevölkerung während der jüngsten Entwicklungen, Stand: Ende Oktober 1989, 31. Oktober 1989, k. 103.

74 Przykładowo: 40\% uczniów zawodu wyrażało zrozumienie dla wyjazdów, wśród studentów było $36 \%$ zrozumienia, wśród uczniów $-29 \%$ i wśród osób pracujących $-28 \%$. G. Thiele, Das politische Profil von Lehrlingen im November 1989 - im Vergleich zu Schülern und Studenten: 
i agresji, którym towarzyszyły obawy o przyszłość własną i kraju ${ }^{75}$. Wielu czyniło sobie wyrzuty, że nie mieli odwagi wyjechać/uciec, co skutkowało niespotykaną do tej pory otwartością w dyskusjach, praktycznie każdy miał bowiem w swoim otoczeniu osobę, która wyjechała/uciekła z NRD. W analizie BND mowa była nawet o szoku, jaki wywołały masowe wyjazdy z NRD. Od połowy września 1989 roku zaznaczył się nowy ruch - ruch opozycyjny wobec ruchu Wir-wollen-raus. Pojawiły się też nowe hasła: Wir -bleiben-hier ${ }^{76}$, których autorami byli dotychczasowi opozycjoniści. Zauważono zmianę zachowań: masowy udział demonstracjach (np. 200 tys. w Lipsku), a także uaktywnienie się ludzi starszych, do tej pory raczej niewidzianych na tego typu manifestacjach. Powoli rodził się duch optymizmu, a przy okazji ujawniły się dotychczas skrywane animozje między północą a południem kraju, co wynikało z rzekomej pasywności północy. Jak wynika z analizy BND, postawa północy wywołała wściekłość południa, która przejawiała się agresją i wyzwiskami (Fischköppe, Doofköppe, rote Mecklemburger). Atakowano kierowców i samochody z rejestracją z Rostocka, Neubrandenburga czy Schwerina: nie obsługiwano ich na stacjach benzynowych czy przecinano im opony ${ }^{77}$.

9 listopada 1989 roku zmieniły się diametralnie możliwości wyjazdu, co oczywiście przełożyło się na liczbę osób, które opuściły NRD: do końca 1989 roku było to już 344 tys. osób, z tego $75 \%$ stanowili ludzie młodzi ${ }^{78}$. Więcej i dokładniej na temat nastrojów związanych z wyjazdami mówiły wyniki reprezentatywnych badań ZfJ. Podczas sondażu przeprowadzonego pod koniec listopada 1989 roku zadano pytania odnoszące się do pozostania lub opuszczenia NRD. 83\% respondentów na pewno chciało pozostać $\mathrm{w}$ NRD, $16 \%$ twierdziło, że najprawdopodobniej pozostanie, a zaledwie $1 \%$ chciało wyjechać. Najbardziej zdecydowanymi do pozostania w NRD były kobiety. Rozpatrując te dane pod względem wiekowym, to 72\% osób w wieku 15-24 lata chciało pozostać w NRD (natomiast wyjechać chciało jedynie 3\%), w grupie wiekowej 25-34 lata pozostanie w NRD deklarowało 79\% (wyjazd 1\%), w grupie 35-44 lata - zamierzało pozostać $81 \%$. Wraz z wiekiem wzrastała liczba osób, które nie chciały wyjechać z NRD - w grupie $65+$ było to już $98 \%{ }^{79}$.

Ergebnisse der Meinungsumfrage 1 (MI). Leipzig 1990: Zentralinstitut für Jugendforschung (ZfJ). https://nbn-resolving.org/urn:nbn:de:0168-ssoar-403782 (dostęp:12 maja 2020).

75 Interesujące było to, że młodzi ludzie, którzy chcieli zostać w NRD mieli większe obawy zarówno z powodu sytuacji gospodarczej, jak i wzrastającej przemocy. Najwyraźniej czuli się bardziej odpowiedzialni za przyszły rozwój NRD.

76 Jak wynika z analizy BND (jej częścią było zbieranie dowcipów i haseł z demonstracji), w październiku 1989 roku pojawiły się nowe hasła, np.: Gehen ist silber, Bleiben ist Gold, Bleibt im Land und wehre dich täglich.

77 BAK, B 206/ 573, k. 102-105, DDR-Innenpolitik, hier: Stimmungswandel in der DDR Bevölkerung während der jüngsten Entwicklungen, Stand: Ende Oktober 1989, 31. Oktober 1989, k. 104-105. Zob. również edycje źródeł BND: Dokument 2861, Titel/Betreff: Unruhe soll in den Norden getragen werden, Z.d.F.: Ende Oktober 1989, 25 Jahre Mauerfall. Dokumente aus den Akten des BND, Mitteilungen der Forschungs- und Arbeitsgruppe „Geschichte des BND”, Im Auftrag des Bundesnachrichtendienstes Nr. 8, 2014, s. 42.

78 ZfJ, Ergebnisse der DDR-repräsentativen Meinungsumfrage M 3...

79 Ibidem; Por. A. Hahn, Der Wandel beginnt. Einführende Daten und Fakten, w: R. Schwarzer, M. Jerusalem (red.), Gesellschaftlicher Umbruch als kritisches Lebensereignis. Psychosoziale Krisenbewältiung von Übersiedlern und Ostdeutschen, Juventa, München 1994, s. 49-104. 
Ciekawe były powody, dla których obywatele NRD chcieli opuścić swój kraj. Zgodnie $\mathrm{z}$ analizą przygotowaną przez Stasi istniało osiem powodów decydujących o opuszczeniu miejsca zamieszkania: niezadowolenie z poziomu zaopatrzenia w NRD; rozgoryczenie z powodu niewystarczającego poziomu usług; brak usprawiedliwienia dla niedociągnięć w opiece medycznej; ograniczone możliwości podróży wewnątrz NRD i za granicę (głównie do zachodnich krajów); niezadowalające warunki pracy i brak ciągłości procesu produkcyjnego; niedociągnięcia / niespójności w stosowaniu / wdrażaniu zasady wydajności pracy, a także niezadowolenie z kształtowania się wynagrodzeń za pracę; oburzenie z powodu biurokratycznych zachowań kierowników i pracowników organów państwowych, firm i instytucji oraz ich bezduszność w kontaktach z obywatelami; brak zrozumienia dla polityki medialnej $\mathrm{NRD}^{80}$. Ogólnie rzecz biorąc, powodem wzmożonej migracji z NRD miało być niezadowolenie z sytuacji społeczno-gospodarczej. Należy jednak mieć na uwadze, że dane te zbierane były przez Stasi, więc możliwe było ,,przeoczenie” niektórych politycznych powodów wyjazdów. Z drugiej jednak strony najwięcej wyjeżdzających pochodziło z południowej części NRD, gdzie poziom życia był niższy niż na obszarach na północ od Berlina ${ }^{81}$.

Do znacznego wzrostu liczby wyjeżdzających doszło między listopadem 1989 roku a lutym 1990 roku, gdy ok. 2,3-2,5 tys. osób przesiedlało się codziennie do RFN. Wszystko wskazywało na to, że w 1990 roku do RFN wyjedzie 400-700 tys. osób obywateli NRD. W tym czasie jedynie $62 \%$ deklarowało, że na pewno pozostanie w NRD (33\%, że prawdopodobnie, 4\% prawdopodobnie wyjedzie i $1 \%$ na pewno wyjedzie $)^{82}$. Bardzo ciekawe były wyniki badań wśród młodzieży: w lutym 1990 roku 12\% osób w grupie wiekowej 15-24 lata chciało wyjechać z NRD. Równocześnie wzrosła akceptacja wyjazdów: na przełomie stycznia i lutego 1990 roku 58,5\% obywateli deklarowało zrozumienie dla osób opuszczających NRD ${ }^{83}$. W marcu 1990 roku sytuacja nieco złagodniała i zmniejszyła się liczba osób chcących opuścić kraj. Wśród osób młodych było to już tylko $6 \%$, wśród wszystkich grup wiekowych było to 3\% W skali państwa oznaczało to 500 tys. osób, w tym 120 tys. osób młodych ${ }^{84}$.

Widoczne różnice w deklaracjach wyjazdów do RFN mogły mieć związek zarówno z postępem zmian zachodzących w NRD (wybory z 18 marca 1990 roku, zapowiedź reformy walutowej), jak i ze zmianą stosunku obywateli RFN do setek tysięcy przesiedleńców z NRD. W prasie zachodnioniemieckiej zaczęły ukazywać się teksty, które wskazywały na problemy natury ekonomicznej związane z koniecznością ich przyjęcia $^{85}$. Wskazywano na problemy z miejscem pracy, mieszkaniem, a także załamaniem

80 W.-D. Cusack, C.Johnson et al. (red.), Der Drang nach Westen. Zur Analyse der Volkskammerwahl, FIB Papers, Wissenschaftszentrum für Sozialforschung Veröffentlichungsreihe der Forschungsgruppe Internationale Beziehungen, Juni 1990, s. 12.

81 Der Drang nach Westen..., s. 12.

82 ZfJ, Ergebnisse der DDR-repräsentativen Meinungsumfrage $M 2 \ldots$

83 ZfJ, Ergebnisse der DDR-repräsentativen Meinungsumfrage M 3...

84 Ibidem.

85 W zasadzie krytyczne teksty odnoszące się do przesiedleńców i uchodźców z NRD pojawiały się już w październiku 1989 roku i dotyczyły głównie Berlina Zachodniego. Z czasem sytuacja zaostrzyła się: w listopadzie 1989 roku miały miejsce w RFN podpalenia i napady na pojazdy 
się systemu ubezpieczeń społecznych $\mathrm{w} \mathrm{RFN}^{86}$. Wiele robiono, aby nie zachęcać do przesiedleń. Przykładem takich działań mógł być problem z zatrudnianiem w Niemieckim Federalnym Urzędzie Poczty (Deutsche Bundespost), gdzie gremialnie odmawiano zatrudnienia obywatelom NRD, zgodnie z wytycznymi dyrekcji Bundespost. Fragment pisma w tej sprawie opublikowany został w tygodniku „Der Spiegel”: „Ze względu na okoliczności polityczne i kierunek polityki rządu federalnego nie należało zachęcać ludności NRD do przeprowadzki”. Zainteresowanym pracą udzielano odpowiedzi negatywnej, której treść została wcześniej odgórnie ustalona ${ }^{87}$.

Jak wynika z badań przeprowadzonych na zlecenie tygodnika „Stern” (1990, nr 10), a także tekstów opublikowanych w tygodniku „Der Spiegel”, w RFN wzrastała niechęć do przesiedleńców spowodowana obawami przed rozsadzeniem systemu opieki społecznej, konkurencji na rynku pracy i mieszkań. Przerażała liczba osób napływających z NRD: tylko w pierwszym tygodniu lutego było to 14,5 tys., w całym miesiącu miało to być ok. 58 tys. osób ${ }^{88}$. Według informacji opublikowanych w tygodniku „Stern” (1990, nr 10), 68\% obywateli RFN opowiedziało się przeciwko dalszemu przyjmowaniu przesiedleńców z NRD, co wskazywało jednoznacznie na zmianę początkowo bardzo optymistycznego nastawienia do przemian w NRD i fali migracji (w czerwcu 1989 roku 70,6\% obywateli RFN opowiadało się za zjednoczeniem Niemiec, przeciwko było $10,6 \%$, obojętny stosunek wykazywało $17 \%)^{89}$.

Niepochlebny obraz przesiedleńców z NRD pojawił się również $\mathrm{w}$ analizach BND i pochodził z okresu znacznej intensywności przesiedleń (1 lutego 1990 roku $)^{90}$. Określając główne przyczyny emigracji z NRD, zwrócono uwagę na czynnik ekonomiczny i dążenie do natychmiastowego osiągnięcia dobrobytu. Według analityków BND to nie tylko motor napędowy wyjazdów z NRD, lecz także główny czynnik determinujący proces zjednoczenia. Dla obywateli NRD nie miały większego znaczenia trudności mieszkaniowe (w NRD nie było przecież lepiej), natomiast ważną kwestią było miejsce pracy, której najczęściej poszukiwano przed podjęciem decyzji o wyjeździe

z NRD. Krytykowano szturm na sklepy i wykupywanie artykułów za Begrüßungsgeld (każdy Niemiec odwiedzający RFN otrzymywał jednorazowe świadczenie w wysokości 100 DM). Do świadczenia uprawnieni byli również Niemcy zamieszkujący Polskę). Poza tym przyjeżdzający z NRD mogli bezpłatnie odwiedzać muzea, baseny i teatry. Pojawiły się również problemy z kradzieżami sklepowymi i źle zaparkowanymi samochodami, co dodatkowo zaogniało sytuację.

${ }^{86}$ Da brennt die Sicherung durch, „Stern” 22 stycznia 1990; Wieso kommen die noch?, „Der Spiegel”, 19 lutego 1990.

87 Einheits-Absage, „Der Spiegel”, 22 stycznia 1990.

88 Wieso kommen die noch?...; Ogólna liczba osób, które osiedliły się w RFN w 1989 roku, wynosiła ponad 842 tys., w tym: 343 tys. emigrantów, a także 377 tys. emigrantów z Europy Wschodniej i 121,3 tys. osób z całego świata ubiegających się o azyl - ogółem 842,2 tys. osób.

89 B. Szummi, I. Lichtleitner, F. Bauske, Datenport...

90 BAK, B 206/535, k. 301-304, Bundesnachrichtendienst, der Präsident, Betr.: DDR - Entwicklung des Übersiedlungsproblems, Pullach, den 01. Februar 1990. Jak wynika z rozdzielnika, analizę przesłano do Urzędu Kanclerskiego i ministerstw federalnych: Ministerstwa Spraw Zagranicznych, Ministerstwa Spraw Wewnętrznych, Ministerstwa Obrony, Ministerstwa Gospodarki, Ministerstwa Stosunków Wewnątrzniemieckich. 
(np. podczas krótkich pobytów w RFN) ${ }^{91}$. Takie zachowania były typowe dla osób młodych i stanu wolnego. Inną strategię przyjęły osoby związane rodzinnie, które nierzadko pozorowały przesiedlenia: ojciec rodziny znajdował pracę w RFN, a rodzina nadal pozostawała w NRD. Celem było zabezpieczenie korzyści materialnych rodzinie, z jednoczesnym zachowaniem więzów z dotychczasowym miejscem zamieszkania (na wypadek znaczącego polepszenia sytuacji w NRD) ${ }^{92}$. Co ciekawe, z badań prowadzonych pod koniec listopada przez ZfJ z Lipska wynikało, że w opinii obywateli NRD możliwość wyjazdów miała ograniczyć liczbę osób emigrujących na stałe - tego zdania było ponad $77 \%$ badanych ( $5 \%$ miało inne zdanie). Można zatem sądzić, że wyjazdy miały głównie podtekst materialny ${ }^{93}$. W BND przewidywano natomiast, że w wielu wypadkach ostateczna decyzja o wyjeździe z NRD uzależniona jest od wyników wyborów parlamentarnych wyznaczonych na marzec 1990 roku.

Cechami charakterystycznymi przesiedleńców były też ich deficyty w wykształceniu i stan wolny. Badania przeprowadzone przez BND wśród osób przesiedlonych z NRD wykazały, że 57\% to osoby młode (20-30 lat), 77\% nie miało zawodu, ewentualnie było do jakiegoś jedynie przyuczone, $45 \%$ było stanu wolnego, a $18 \%$ rozwiedzionych. Zauważono przy tym dość powszechne zjawisko podwyższania znaczenia wykonywanego wcześniej zawodu dla uzyskania lepszych szans na nowe miejsce pracy: pracownicy rolni stawali się technikami agrarnymi lub hodowcami bydła, a pomocnicy na budowie określali się murarzami lub tynkarzami ${ }^{94}$. Tendencja ta utrzymała się przez następne tygodnie, o czym świadczyć mogą wyniki badań z 19 lutego 1990 roku: o 1 punkt procentowy zwiększyła się liczba osób młodych i o 5 punktów procentowych osób stanu wolnego, równocześnie zmniejszyła się o 6 punktów procentowych grupa osób bez zawodu ${ }^{95}$. Nowym zjawiskiem był udział osób z wykształceniem wyższym, które decydowały się na wyjazd, co miało najprawdopodobniej związek z dyskusją o reformie gospodarczej i unii walutowej budzące duże zaniepokojenie. Skutkiem był zauważalny wzrost liczby przesiedleńców - do końca lutego miało przesiedlić się ok. 120 tys. osób (taką liczbą osiągnięto w 1989 roku dopiero pod koniec października).

W rzeczywistości w pierwszych dwóch miesiącach 1990 roku do RFN przesiedliło się ponad 137 tys. osób ${ }^{96}$. W BND sądzono, że rosnąca tendencja wyjazdowa utrzy-

91 Według danych pozyskanych pod koniec listopada 1989 roku aż 46,1\% mieszkańców NRD było w ostatnich dniach $\mathrm{z}$ wizytą w RFN, a 51,2\% nosiło się z takim zamiarem. Oznaczało, to że do końca 1989 roku ponad 97\% miało przekroczyć granicę niemiecko-niemiecką. ZfJ $S$ 6018, Meinungsumfrage November 1989 - Einstellung zur Entwicklung in der DDR; W tym miejscu należy przypomnieć, że do końca grudnia 1989 roku każdy obywatel NRD otrzymywał 100 DM Begrüßungsgeld, co było potężnym wydatkiem, zważywszy na liczbę odwiedzających RFN. Jak wynika z obliczeń szacunkowych, w końcowym okresie obowiązywania tego świadczenia (listopad-grudzień 1989 roku) wypłacono ok. 3-4 mlrd DM.

92 Tego typu działania nazywane były przez administracje NRD Wohlstandswohnsitznahme, co można luźno przetłumaczyć jako „rezydencja dobrobytu”. W lutym 1990 roku nie można było określić wielkości tego zjawiska.

93 ZfJ S 6018, Meinungsumfrage November 1989...

94 BAK, B 206/535, k. 301-304, Bundesnachrichtendienst..., k. 304.

95 BAK, B. 206/535, k. 104-106, Pr-Info, Betr.: Übersiedelung in die Bundesrepublik Deutschland - aktuelle Situation, Hinweis: Ergänzung der Pr-Info vom 30. Januar1990, k.105.

96 A. Hahn, Geschichte und Szenarien der Übersiedlung..., s. 23-48. 
ma się do jesieni 1990 roku, czyli planowanych wyborów do Bundestagu i możliwej zmiany kanclerza. Obywatele NRD obawiali się, że jakakolwiek zmiana polityczna w RFN wpłynie na ich możliwości przesiedlenia się, dlatego wiele osób planowało to jeszcze przed wyborami. W praktyce w następnych miesiącach wyraźnie spadła liczba osób pragnących osiedlić się w RFN: w marcu było to 46241 osoby, w kwietniu - 24 615, w maju - 19217 i w czerwcu - 10 686. Wszystkie dane pochodzą z Federalnego Urzędu ds. Odszkodowań (Bundesauschgleichamt) ${ }^{97}$. Nie wiadomo, jaki realny wpływ na decyzję o pozostaniu w NRD miały rozstrzygnięcia rządu RFN z marca 1990 roku, kiedy to zniesiono ustawę imigracyjną z 1950 roku (Gesetz über die Notaufnahme von Deutschen in das Bundesgebiet). Odpowiednie przepisy weszły w życie 24 czerwca 1990 roku ze skutkiem od 1 lipca 1990 roku. Nowa regulacja zaczęła obowiązywać równolegle z wejściem w życie unii gospodarczej, walutowej i społecznej (Die Währungs-, Wirtschafts- und Sozialunion). Każdy, kto przyjechał do RFN po 1 lipca 1990 roku, był traktowany jako obywatel niemiecki i nie otrzymywał wsparcia na zintegrowanie się w nowym miejscu zamieszkania ${ }^{98}$.

\section{Zakończenie}

W kwietniu 1990 roku zakończyły się badania sytuacji społeczno-politycznej w NRD prowadzone przez BND. Z racji przemian, jakie zachodziły w tym kraju, nie było już potrzeby dalszego prowadzenia przez BND tajnych badań, co oczywiście nie wyklucza gromadzenia wyników analiz na temat sytuacji politycznej i społecznej NRD aż do końca istnienia tego państwa ${ }^{99}$. Na pewno informacje o nastrojach w NRD opracowane przez BND lub pozyskane z sondaży instytutów wschodnioniemieckich mogły przygotować decydentów w RFN na potencjalny rozwój sytuacji w NRD. Czy sugerowano się nimi w Urzędzie Kanclerskim i czy wyniki sondaży wpłynęły na działania rządu RFN, a także na formę i treść kampanii wyborczej w marcu 1990 roku? $\mathrm{Z}$ obecnie dostępnej literatury wynika, że kanclerz federalny nie kierował się wynikami badań nastrojów wśród Niemców wschodnioniemieckich, a nawet ich nie czyta1 ${ }^{100}$. Uważam jednak, że z ostateczną oceną znaczenia tych badań należy poczekać do czasu udostępnienia wszystkich materiałów archiwalnych odnoszących się do tego tematu. Pewne natomiast jest, że wielka fala uchodźców i przesiedleńców, jaka wystąpiła w okresie od późnego lata 1989 roku do marca 1990 roku, stała się symbolem zachodzących przemian i dążeń Niemców z Niemiec Wschodnich do zjednoczenia. Wielu badaczy jest zdania, że punktem wyjścia procesu załamania politycznego w NRD był nie tyle ostry kryzys gospodarczy czy zaopatrzeniowy, co raczej widoczny od lata 1989

\footnotetext{
97 Ibidem.

98 Ibidem, s. 33-34.

99 Informacje o nastrojach społecznych gromadzone były przez Stasi praktycznie do końca istnienia NRD, o czym pisze Tytus Jaskułowski, Nachrichten aus einem Land, das doch existierte. Lageberichte aus den Bezirken für die letzte DDR-Regierung 1990, OEZ Berlin Verlag, Berlin 2012. 100 Pytaniem otwartym pozostaje, czy analizy te czytały osoby z najbliższego otoczenia kanclerza, a szczególnie osoby odpowiedzialne za kształt kampanii wyborczej i aktywność Kohla w NRD, w tym również treść jego przemówień, określanych często jako obietnica „blühende Landschaften”.
} 
roku znaczny wzrost wyjazdów do Republiki Federalnej, który pod koniec listopada 1989 roku osiągnął swoją kulminację ${ }^{101}$. Wyjazdy te miały zarówno charakter nielegalny (ucieczka - Flucht), jak i legalny (przesiedlenie - Übersiedlung). Bezradność rządu NRD, a także „exodus w kierunku jedności”102 i aktywność grup opozycyjnych doprowadziły do ukształtowania nowego systemu partyjnego w NRD. W wyniku przyspieszonych wyborów do Izby Ludowej z 18 marca 1990 roku w NRD wykrystalizował się nowy układ polityczny pozwalający na utworzenie rządu uzależnionego od pomocy $\mathrm{RFN}^{103}$. Droga do zjednoczenia została otwarta, a występująca przez cały okres powojenny abstrakcja zjednoczenia nabrała realnych form. Wkrótce również mur - symbol podziału Niemiec - przestał istnieć, chociaż jeszcze w styczniu 1989 roku Honecker twierdził: „,[Mauer] wird in 50 und auch in 100 Jahren noch bestehen bleiben"104.

Tendencje migracji ze wschodu na zachód utrzymały się również w czasie późniejszym. Jak wynika z badań przeprowadzonych w listopadzie 2019 roku dotyczących przemieszczeń wewnątrzniemieckich, jedynie $2 \%$ mieszkańców byłego NRD nie była w ostatnich trzydziestu latach (od otwarcia granicy niemiecko-niemieckiej) w zachodnich krajach związkowych, 48\% z nich było tam więcej niż 10 razy (wśród obywateli Niemiec Zachodnich nigdy nie było na wschodzie kraju $17 \%$, natomiast $22 \%$ było tam więcej niż 10 razy) ${ }^{105}$. Nierówna jest też ocena samego zjednoczenia niemiecko-niemieckiego. Była ona zróżnicowana zarówno w okresie do 1989 roku, jak i w czasie gwałtownych zmian z przełomu lat 1989/1990, o czym świadczyły przytoczone wyniki badań. Również współcześnie ocena tego procesu nie jest jednolita, na co wskazują wyniki badań stanu zjednoczenia Niemiec z czerwca 2019 roku. Wówczas 66\% ankietowanych ze wschodnich landów wskazało, że nadal dominują różnice między wschodnią a zachodnią częścią kraju. Tego zdania było także 55\% ankietowanych ze „starych” landów ${ }^{106}$.

\section{Abstract \\ The Attitude of East German Citizens towards the German Reunification and Resettlements to Germany in the Light of Secret Opinion Polls (Autumn 1989-Spring 1990)}

During the socio-political breakthrough (autumn 1989-spring 1990), institutions in the German Democratic Republic (GDR) and the Federal Republic of Germany

\footnotetext{
101 R. Ulrich, Die Übersiedlerbewegung in die Bundesrepublik und das Ende der DDR [P 90-302], FIB Papers, Wissenschaftszentrum Berlin für Sozialforschung, Berlin 1990.

102 A. Hahn, Geschichte und Szenarien der Übersiedlung, s. 32.

103 E. Cziomer, Przesłanki konfliktu Wschód-Zachód, s. 245.

104 Cyt. za A. Hahn, Geschichte und Szenarien der Übersiedlung, s. 29.

105 Wie oft waren Sie seit dem Mauerfall 1989 privat in den alten Bundesländern / in den neuen Bundesländern, außer Berlin? Wenn Sie mir eine ungefähre Zahl nennen, dann reicht das aus. Statista https://de.statista.com/statistik/daten/studie/1069389/umfrage/reisen-in-den-anderen-teil -deutschlands/ (dostęp: 15 lipca 2020).

106 Überwiegen zwischen dem Westen und dem Osten Deutschlands eher die Unterschiede oder eher die Gemeinsamkeiten? Statista, https:/de.statista.com/statistik/daten/studie/918339/umfrage/ einschaetzung-zu-stand-der-wiedervereinigung-in-west-und-ostdeutschland/ [15.07.2020]
} 
conducted public opinion polls aimed at finding out the opinion of East German society on current, often polarising, topics. The leading issues included the attitude of East German citizens to the reunification of Germany and the problem of increased departures to Germany. Of course, the research was not limited to these two issues, but contained a whole range of other questions that allowed the views and political activity of GDR society in late 1989 and early 1990 to be examined. The study is based on archival materials produced by the Federal Intelligence Service (Bundesnachrichtendienst) and deposited in the Federal Archives in Koblenz (Bundesarchiv), as well as materials from the GESIS - Leibniz Institute for the Social Sciences collections available online. These are supplemented by German-language literature.

Keywords: German reunification, West Germany, East Germany, Bundesnachrichtendienst (BND), opinion polls, 1990, H.-G. Wieck. 